\title{
Phytochemical Screening and Antimicrobial Activity of Carica Papaya L, Citrus Paradisi L, Citrus Sinensis L, and Vernonia Amygdalina Del. Cent
}

\author{
Nduche MU*, Nkaa FA and Onyebinime A \\ Department of Plant Science and Biotechnology, Michael Okpara University of Agriculture, Nigeria
}

Submission: January 12, 2019 ; Published: January 30, 2019

*Corresponding author: Nduche MU, Department of Plant Science and Biotechnology, Michael Okpara University of Agriculture, Umudike PMB 7267 Umuahia Abia State, Nigeria

Abstract

The antimicrobial activity and phytochemical analysis were carried out on the leaves of Carica papaya L, Citrus paradise L Citrus sinensis $\mathrm{L}$ and Vernonia amygdalina. The aim of the work is to determine the phytochemical contents, diameter of inhibition and minimum inhibition concentration of the grasses studied. The four-plant species were found to contain alkaloid, saponin, tannins, flavonoid and phenols in varying proportions. The phytochemical contents of $C$. papaya (Pawpaw) were as follows: alkaloid $(1.11 \pm 0.02 \%)$, saponins $(0.53 \pm 0.04 \%)$, tannin $(0.43$ $\pm 0.4 \%$ ), flavonoid $(0.67 \pm 0.01 \%)$ and phenols $(0.91 \pm 0.03 \%)$. For Citrus Paradisi (Grape) alkaloid content was $(0.31 \pm 0.05)$, saponins $(0.19 \pm$ $0.01)$, tannins ( $0.25 \pm 0.01$ ), flavonoid $(0.36 \pm 0.02)$, phenol ( $0.52 \pm 0.04)$. In Citrus sinensis (Orange), alkaloid was $(0.23 \pm 0.01)$, saponin $(0.23 \pm$ 0.01 ), tannin ( $0.15 \pm 0.01)$, flavonoid $(0.33 \pm 0.01$ ) and phenol ( $0.59 \pm 0.07$ ). For Vernonia amygdalina Del. Cent (Bitter leaf), alkaloid (1.31 \pm 0.03$)$, saponin (1.15 \pm 0.01$)$, flavonoid $(0.71 \pm 0.02)$, tannin $(0.43 \pm 0.01)$, phenol $(1.15 \pm 0.01)$.

The anti-microbial activity of the ethanolic and aqueous extracts of leaves of the plants were tested against four microorganisms; Salmonella pullorum, Klebsiella pneumonia, Enterobacter aerogenes and Proteus vulgaris. The susceptibility of the microorganisms was determined using the disk diffusion method. The leaf extract of these plants inhibited the growth of these pathogens. All the ethanolic leaf extracts of the plants inhibited the clinical isolates. The minimum inhibitory concentration was analyzed using agar well diffusion method with values ranging between $50 \mathrm{mg} / \mathrm{ml}$ and $200 \mathrm{mg} / \mathrm{ml}$ against all the clinical isolates. There were variations in the lowest concentrations of the different plant extracts that caused inhibitions against the various microorganisms.

Keywords: Antimicrobial; Microorganisms; Medicinal; Phytochemicals; Nigeria

\section{Introduction}

Plants are rich in a wide variety of secondary metabolites with anti-microbial properties such as flavonoid, tannins, phenols and alkaloids [1]. The study of most research recently is to evaluate the anti-microbial activity of some local natural plants which have potential of treating infectious diseases and with reduced side effects compared to the synthetic drug agents [2]. The use of plant extracts and phytochemicals, both with known antimicrobial properties can be of great significance in the treatment of diseases. Many plants have been used because of their anti-microbial properties. This is mostly due to synthesis of secondary metabolism by the plants [3]. Discovery of new antimicrobial compounds with diverse chemical structures and novel mechanism of action becomes of urgent attention. Currently, the development of resistant strains of bacteria has increased the need for new antibiotics the antimicrobial compounds produced by plants are active against plants and human pathogenic microorganism [4]. Isolation of bacteria less susceptible to regular antibiotics and recovery of resistant isolates during antibacterial therapy is now a global problem
[5]. In developing countries, the situation is even worse because of poor sanitation and ignorance of good hygiene practice thus exposing many people to infectious agents.

Phytochemicals are chemical compounds that occur naturally in plants. They are chemicals produced by plants through primary or secondary metabolism [6-8]. Some are responsible for color and other organoleptic properties, such as the deep purple of blueberries and the smell of ginger. Plants are composed entirely of chemicals of various kinds Phytochemical has bio-active constitutes such as alkaloids, tannis, flavonoids, saponins and phenolic compounds [9]. The medicinal values of some plants lie in these chemical substances that produce definite physiological actions in the human body. Many of these indigenous medicinal plants are used as spices and food plants [10]. Plant serves as rich resources of natural drugs for research and development. The beneficial medicinal effects of plant materials typically result from the combinations of secondary products present in plants. The medicinal actions of plants are unique to plant species or groups as the com- 
bination of secondary products in a plant are often taxonomically distinct [11].

\section{The Aim and Objectives of this Work are}

a. To determine the phytochemicals of Citris paradisi (grape), Citrus sinensis C. (orange), Carica papaya (paw-paw) and Vernonia amygdalina (bitter leaf).

b. To determine antimicrobial activities of the aqueous and ethanolic leaf extracts of Carica papaya, Citris paradisi, Citrus sinensis and Vernonia amygdalina, on Salmonella pullorum, Klebsiella pneumonia, Enterobacter aerogenes and Proteus vulgaris

The genus Carica belongs to the family Caricaceae which is usually a single-stemmed, semi-woody giant herb with fast, indeterminate growth;3m during the first year [12]. Carica papaya is a sole species of the genus Carica. Caricaeceae, a family well represented in the neotropics that includes six genera with at least 35 species It is spread to many tropical and subtropical regions around the world [13]. The plant produces large palmate leaves $\left(0.6 \mathrm{~m}^{2}\right)$ with five to none pinnate lobes of various widths between 40 to $60 \mathrm{~cm}$ the papaya plant develops very fast taking 3-8 months from seed germination to flowering and 9-15 months for harvest. Stem grows from 5 to $10 \mathrm{~m}$ (16 to $33 \mathrm{ft}$ ) tall, with spirally arranged leaves confined to the top of the trunk. The lower trunk is conspicuously scarred when the leaves and fruit were borne. The leaves are large, $50-70 \mathrm{~cm}(20-28 \mathrm{~m})$ in diameter, deeply palmately lobed, with seven lobes, all parts of the plant contain latex [14]. The ripe fruit of papaya is usually eaten raw without skin or seeds. The unripe green fruit can be eaten cooked, usually in curries, salads and stew. The leaves are used in herbal medicine to remove intestinal worms

Citrus paradise (grape) belong to the family Rutaceae, order Sapindales and species Citrus paradisi, it is a subtropical citrus tree known for its sour to semi-sweet somewhat bitter fruit The evergreen grape fruit trees usually grow to around 5-6 meters (16$20 \mathrm{ft})$ tall, though they can reach $13-15 \mathrm{~m}(43-49 \mathrm{ft})$, the leaves are glossy dark green, long (up to 15 centimeters (5.9inches) and thin. The fruit is yellow-orange skinned and generally an oblate spheroid in shape, it ranges in diameter from $10-15 \mathrm{~cm}$ (3.9-5.9inches). The flesh is segmented and acidic varying in color depending on the cultivars which include, white, pink and red pulps of varying sweetness. Grape has been investigated in cancer medicine pharmacodynamics and good source of vitamin C [15].

The genus citrus belongs to the family Rutaceae. The orange tree is evergreen, flowering tree, with an average height of 9 to $10 \mathrm{~m}$ (30 to 33ft), although some very old specimens can reach $15 \mathrm{~m}$ (49ft). The leaves are oval, alternatively arranged 4 to $10 \mathrm{~cm}$ and have crenulate margins. Sweet orange grows in range of different sizes, and shapes varying from spherical to oblong. When unripe, the fruit is green, the irregular rind of the ripe fruit can range from bright orange to yellow-orange. It is widely grown in tropical and sub-tropical climates for their sweet fruit, the fruit can be eaten fresh, or processed for its juice or fragrant peel. As of 2012, sweet orange accounted for approximately $70 \%$ of citrus production. In 2014, 70.9million tones of orange were grown worldwide, with Brazil producing $24 \%$ of the world total followed by China and India. The orange peel is used as a dried seasoning, orange is effective in the management of asthma, arthritis, cholera etc. Citrus sinensis (orange) peel extracts contain bioflavonoids including poly methoxylated flavors, which have anti-inflammatory and hypolipodemic effects [16].

Vernonia amygdalina, a member of the Asteraceae family, is a shrub or small tree of $2-5 \mathrm{~m}$ with petiolate leaf of about $6 \mathrm{~mm}$ diameter and elliptic shape. The leaves are green with a characteristic's odor and a bitter taste. No seeds are produced and the tree has therefore to be distributed through cutting. It grows under a range of ecological zones in Africa, the leaves are washed before eating to get rid of the bitter taste. They are used as vegetable and stimulate the digestive system, as well as to reduce fever.

They are used in medicine as anti-malarial, anti-microbial laxative, anthelmintic, antithrombotic and both hypoglycemic and hypohpidaemic effect in diabetics. It is also used in breast cancer treatment Vernonia amygdalina can also be used alone or in combination with known drugs. Vernonia amygdalina extracts may help suppress, delay or kill cancerous cell in many ways, such as induction of apoptosis as determined in cell culture and animal studies [17]. Other medicinal importance includes, it helps in digestion and reduce fever. Vernonia amygalina also enhances chemotherapy sensitivity, extract may render cancerous cells to be more sensitive to chemotherapy [18].

\section{Materials and Methods}

\section{Collection of Plant Materials and Identification}

The fresh and healthy leaves of the plant species - bitter leaf, paw-paw, grape, orange was obtained from different premise. Carica papaya, Citrus paradise, Citrus sinensis and Vernonia amgydalina were obtained from the premises of Michael Okpara University of Agriculture, Umudike, Abia State. Citrus paradisi was gotten from the premises of National Root Crop Research Institute, Umudike Abia State. It was identified in the taxonomic unit of the Department of Plant Science and Biotechnology, Michael Okpara University of Agriculture Umudike, Abia State.

\section{Preparation of the Sample for Analysis}

The extraction of the plant leaves was carried out using known standard procedures $[19,20]$. The plant samples were oven dried at $45^{\circ} \mathrm{C}$ for 5 hours. The dried samples were milled using Thomas - Willey milling machine and stored in the Central laboratory of National Root Crop Research Institute, Umudike, Abia State. Five grams of the leaf sample was measured out and placed in different conical flasks. Hundred milliliters of water and ethanol were poured in each leaf sample respectively. It was left for 24 hours before the solution was extracted. The extracts were filtered using Whatman filter paper (No 1) and dried over a steam bath. The aqueous and ethanol extracts of the leaf sample yielded a dark 
greenish residue. The extracts were preserved for further investigation for potential anti-microbial activities. The extracts were subjected to preliminary phytochemical testing to detect the presence of different chemicals. Air dried and powdered plant materials were screened for the presence of alkaloids, flavonoids, phenols, saponins and tannins.

\section{Phytochemical Analysis}

\section{Qualitative Analysis on Leaf Extract}

Test for the presence of alkaloids: The presence of alkaloid in the test sample was carried out using the Mayer and Wagner test as described by Sofowara [19]. Two grams of the powdered sample was put into a conical flask and $10 \mathrm{ml}$ of absolute ethanol (98\%) was added into the flask. After shaking vigorously for about 30 minutes, it was filtered and the filtrate was used as the extract. The formation of an orange coloration indicated the presence of alkaloids.

Test for the presence of flavonoids: The presence of flavonoids in the samples was determined by the acid alkaline test method described by Tyler [21]. Two grams of the plant sample was put into test tube and a few drops of concentrated ammonia solution added to it. A yellow coloration was found which turned colorless when few drops of concentrated hydrochloric acid was added to it showing the presence of flavonoid in the sample.

Test for the presence of phenols: The presence of phenols was determined by using the method described by Yadav \& Agarwala [20]. Two grams of the sample was soaked in $10 \mathrm{ml}$ of methanol. After 24 hours, it was filtered using Whatman filter paper (No1). $2 \mathrm{ml}$ of the extract was mixed with a dilute ferric chloride solution. A blue green or black coloration was formed indicating the presence of phenols.

Test for the presence of saponins: The presence of saponin in the samples was determined by the method described by Obadoni \& Ochuku [22]. Two grams of powdered sample was mixed with $5 \mathrm{ml}$ of distilled water in a test tube. The mixture was shaken vigorously. A stable froth (foam) on standing indicates the presence of saponin. In the emulsion test, 3 drops of groundnut oil was added to $2 \mathrm{~g}$ of sample and was mixed with $5 \mathrm{ml}$ of distilled water and shaken well. Formation of emulsion indicated the presence of saponin.

Test for the Presence of Tannins: The presence of tannins in the samples were determined using the method described by Sofowora [19]. Two grams of the sample was soaked in $10 \mathrm{ml}$ of methanol. After 24 hours, it was filtered using Whatman filter paper (No 1). Two milliliters of the extract were mixed with a dilute ferric chloride solution. A greenish black precipitate was formed indicating the presence of tannins.

\section{Quantitative Analysis of Phytochemicals}

Extracts were analyzed for the presence of alkaloids, flavonoids, phenols, saponins and tannins according to Sofawara [19],
Yadav \& Agarwala [20]. Using 2g of each sample, isolation and determination of phenolic compounds were carried out using the soxhlet apparatus for $2 \mathrm{hrs}$. The samples were defatted with 100 $\mathrm{ml}$ of diethyl ether. The defatted samples were heated with $50 \mathrm{ml}$ petroleum for the extraction of the compounds. Five milliliters of the extract were pipetted into a $50 \mathrm{ml}$ flask for about $15 \mathrm{~min}$ and $10 \mathrm{ml}$ of distilled water was added to it. With addition of $5 \mathrm{ml} \mathrm{am-}$ yl-alcohol and $20 \mathrm{ml}$ of aqueous $\mathrm{NH}_{4} \mathrm{OH}$ solution, the complex color was developed. This took place for about $30 \mathrm{~min}$ and the absorbance read with a spectrophotometer.

HCN was determined by the alkaline picrate method modified by Onwuka [23]. $5 \mathrm{~g}$ of the sample was weighed into a plastic tube and $50 \mathrm{ml}$ of distilled water added and homogenized for about 30 minutes. This could incubate for about 18 hours. The solution was filtered into a $50 \mathrm{ml}$ volumetric flask, $2 \mathrm{ml}$ of the extract was pipette into a test tube and $4 \mathrm{ml}$ of alkaline picrate solution added and made up to $10 \mathrm{ml}$ with distilled water. It was heated up in a water bath for about 5 minutes. The optical density of the sample was read at $490 \mathrm{~nm}$ using spectrophotometer. A set of cynide working standards were prepared in a test tube and the color developing solution added and made up to mark, read at $490 \mathrm{~nm}$.

Four grams of ground sample was soaked in $100 \mathrm{~cm}^{3}$ of $2 \% \mathrm{HCl}$ for $3 \mathrm{~h}$ and then filtered through two layers of filter paper $25 \mathrm{~cm}^{3}$ of the filtrate was placed in a $250 \mathrm{~cm}^{3}$ conical flask and $5 \mathrm{~cm}^{3}$ of $0.3 \%$ $\mathrm{NH}_{4} \mathrm{SCN}$ solution was added as an indicator, $53.5 \mathrm{~cm}^{3}$ of distilled water was then added to reach the proper acidity. This mixture was titrated against $\mathrm{FeCl}_{3}$ solution, which contains about $0.00195 \mathrm{~g}$ of $\mathrm{Fe}$ iron per $\mathrm{cm}^{3}$ of $\mathrm{FeCl}_{3}$ solution. The result was multiped by factor 1.95 to obtain phytate P. phytate P result was multiplied by factor 3.55 to convent to phytate.

\section{Determination of Anti-Microbial Activity}

Preparation of the plant extracts: The ethanolic extracts of the leaves of Carica papaya, Citris paradisi, Citrus sinensis and Vernonia amygdalina, were prepared. Five grams of the powdered leaf samples were soaked in $100 \mathrm{ml}$ of ethanol and allowed to stand for 24 - 48 hours. The filtrate was evaporated to dryness over steam bath. The residue was dissolved to obtain the desired plant extract for the anti-microbial test. The aqueous extracts of the leaves of Carica papaya, Citris paradisi, Citrus sinensis and Vernonia amygdalina, were prepared. Five grams of the powdered leaf samples were soaked in $100 \mathrm{ml}$ of absolute water and allowed to stand for 24-48 hours. The filtrate was evaporated to dryness over a steam bath. The residue was dissolved to obtain the desired plant extract for the antimicrobial test.

Sources of Pathogen: Pathogens used in this study were Salmonella pullorum, Klebsiella pneumonia, Enterobacter aerogenes and Proteus vulgaris were obtained from the stock culture of the Veterinary laboratory, Michael Okpara University of Agriculture Umudike Abia State. Viability test of each isolate was carried out by resuscitating the organism cultured in a nutrient agar medium and incubated at $37^{\circ} \mathrm{C}$ for 24 hours. 
Anti-Microbial Test: The sensitivity of the test organism to the ethanolic and aqueous extracts of Citris paradisi, Citrus sinensis, Carica papaya and Vernonia amygdalina, were carried out using the disk diffusion technique described by Cheesebrough [24].

The locally prepared sterile discs were soaked in the water extract for some hours and $7 \mathrm{~g}$ of nutrient agar was dissolved in $250 \mathrm{ml}$ of distilled water and was sterilized using autoclave and the nutrient agar medium was poured in sterile Petri dishes and it could solidify. $1 \mathrm{ml}$ of the test organisms was placed on the solidified agar and it was spread all over the surface of the agar. The soaked discs were placed into the different leaf extract and was picked using sterile forceps and it was dropped on the surface of the agar. Discs should be firm having even contact with the surface of the medium. The plates were incubated at $37^{\circ} \mathrm{C}$ for 24 hours before the reading was taken on the area of growth inhibition. Sensitivity of the organisms was recorded.

\section{Control Experiment using Antibiotics}

To compare the diameter of zone of inhibition from the extracts, the method described by Perez [25] was carried out aseptically where already standardized antibiotic control experiment was employed. This is to encourage the prescription of either antibiotics or the plant leaves with antimicrobial activities. The antibiotic used for the comparison is Gentamycin.

\section{Determination of Minimum Inhibitory Concentration}

The Minimum Inhibitory Concentration (MIC) was determined for the active plant extracts that showed the widest spectrum of antimicrobial activity against test microorganisms. The MIC was considered the lowest concentration of the sample that prevented visible growth. All samples were examined in triplicate. Aliquot of the extract; $0.2 \mathrm{mg}$ was dissolved in $100 \mathrm{ml}$ of distilled water to obtain $2.0 \mathrm{mg} / \mathrm{ml}$. This concentration was then diluted in sterile distilled water to obtain concentration of $200,100,50,25$ and $12.5 \mathrm{mg} / \mathrm{ml}$.

\section{Statistical Analysis}

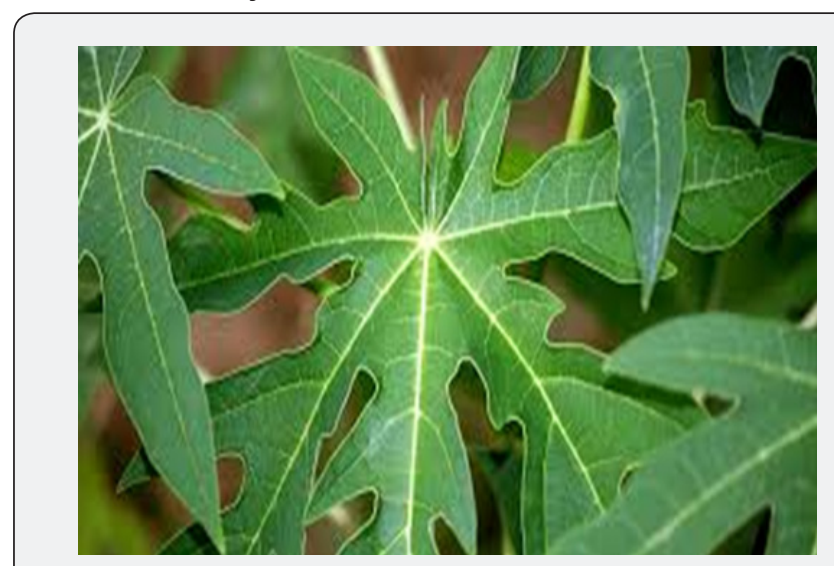

Figure 1: The leaves of Carica papaya

The data obtained is expressed as mean \pm standard error for the diameter of inhibition in each group. The data obtained was analyzed by using the one-way analysis of variance (ANOVA) in all cases, statistical significance was established at values $(\mathrm{P}<0.05)$ (Figures 1-4).

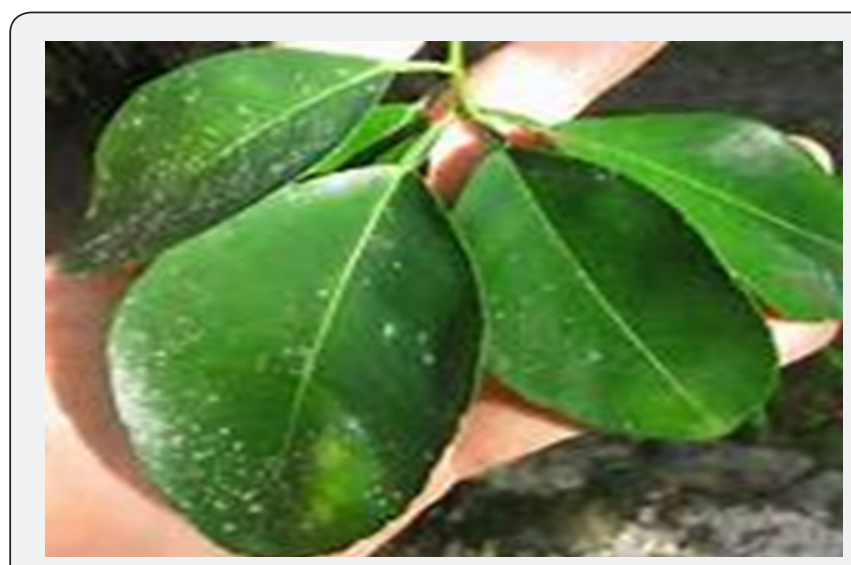

Figure 2: The leaves of Citrus paradise.
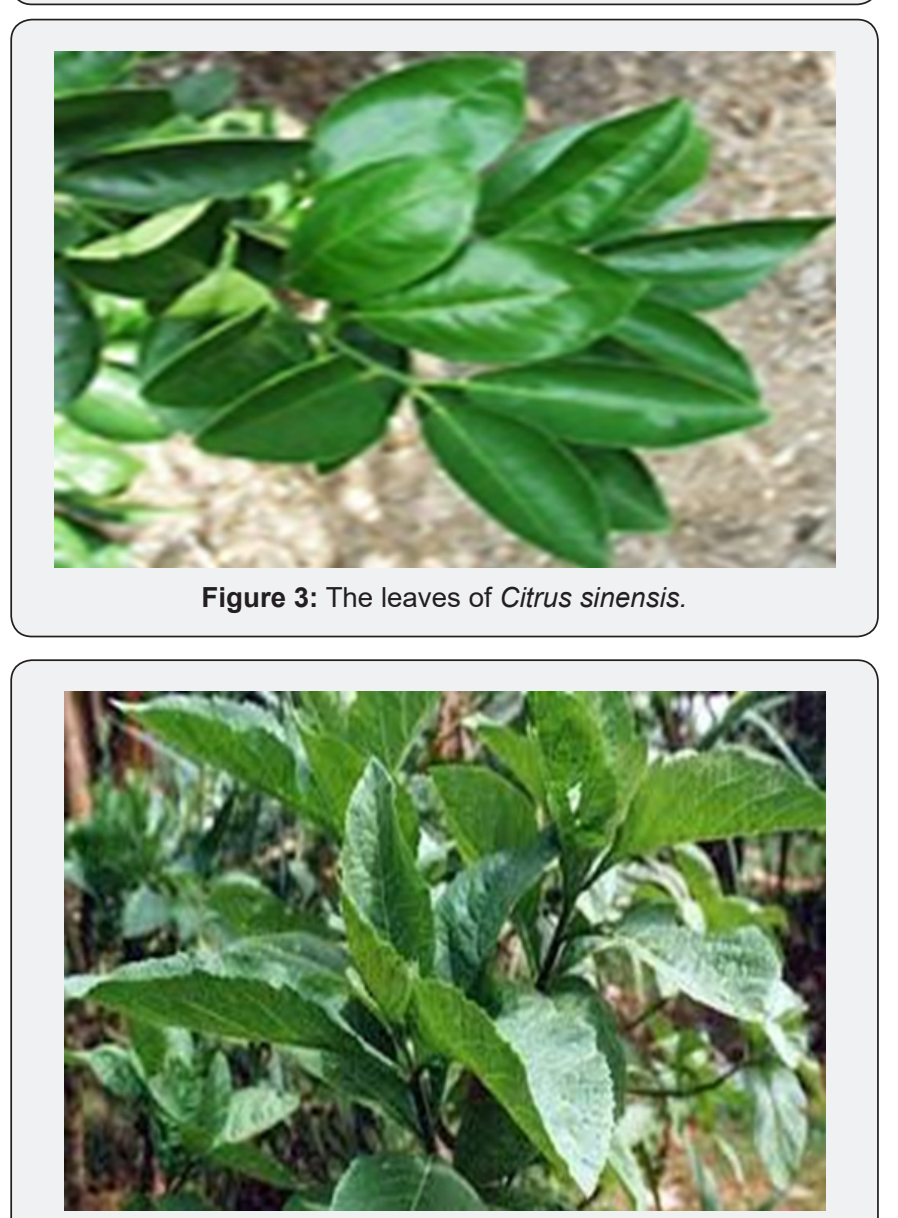

Figure 4: The leaves of Vernonia amygdalina.

Result

\section{Phytochemical Properties}

The result of the phytochemical screening of Carica papaya, Citris paradisi, Citrus sinensis and Vernonia amygdalina, were presented in Tables 1 \& 2 . 


\section{Qualitative Analysis}

The qualitative analysis of the phytochemical presence in Carica papaya, Citris paradisi, Citrus sinensis and Vernonia amygdali- $n a$, are also revealed in Table 1 . All the plant species used for the research contained saponins, tannins, flavonoid, alkaloid, HCN, phytate and phenol.

\section{The Quantitative Analysis}

Table 1: Phytochemical Sample of Test Plants.

\begin{tabular}{|c|c|c|c|c|c|c|}
\hline Sample & Alkaloid & Flavonoid & Tannins & Saponins & Starch & Phenol \\
\hline Carica papaya & +++ & ++ & ++ & ++ & + & + \\
\hline Citrus paradisi & + & + & + & + & - & + \\
\hline Citrus sinensis & + & + & + & + & - & + \\
\hline Vernonia amygdalina & +++ & ++ & + & +++ & + \\
\hline
\end{tabular}

Key: -: Absent

+ : Present slightly

++ : Present moderately

+++ : Present highly

Table 1 show the preliminary phytochemical screening results of leaves of the four-test plant. Alkaloid was detected at high level $(+++)$ in pawpaw and bitter leaf but low in the citrus leaves. All the test phytochemicals were low in the citrus leaves but moder-

ate in pawpaw and bitter leaf. The result in Table 2 show that the concentration of the different phytochemicals varied significantly between the test plants. The high alkaloid content means that the leaves can be useful medicinally.

Table 2: Phytochemical Content of leaves of Test Plants.

\begin{tabular}{|c|c|c|c|c|c|c|c|}
\hline Sample & Alkaloid & Flavonoid & Saponins & Tannins & HCNmg/kg & phytate & Phenol \\
\hline Carica papaya & $1.11^{\mathrm{c}} \pm 0.02$ & $0.67^{\mathrm{c}} \pm 0.01$ & $0.53^{\mathrm{b}} \pm 0.04$ & $0.43^{\mathrm{c}} \pm 0.04$ & $11.25^{\mathrm{d}} \pm 0.25$ & $0.41^{\mathrm{c}} \pm 0.03$ & $0.9^{\mathrm{b}} \pm 0.03$ \\
\hline Citrus paradisi & $0.31^{\mathrm{b}} \pm 0.05$ & $0.36^{\mathrm{b}} \pm 0.02$ & $0.19^{\mathrm{a}} \pm 0.01$ & $0.25^{\mathrm{b}} \pm 0.01$ & $7.07^{\mathrm{c}} \pm 0.16$ & $0.33^{\mathrm{b}} \pm 0.02$ & $0.52^{\mathrm{a}} \pm 0.04$ \\
\hline Citrus sinensis & $0.23^{\mathrm{a}} \pm 0.01$ & $0.33^{\mathrm{a}} \pm 0.01$ & $0.23^{\mathrm{a}} \pm 0.01$ & $0.15^{\mathrm{a}} \pm 0.01$ & $5.67^{\mathrm{a}} \pm 0.42$ & $0.45^{\mathrm{d}} \pm 0.01$ & $0.59^{\mathrm{a}} \pm 0.07$ \\
\hline Vernonia amygdalina & $1.31^{\mathrm{d}} \pm 0.03$ & $0.71^{\mathrm{d}} \pm 0.02$ & $1.15^{\mathrm{c}} \pm 0.01$ & $0.43^{\mathrm{c}} \pm 0.01$ & $3.77^{\mathrm{a}} \pm 0.09$ & $0.27^{\mathrm{a}} \pm 0.01$ & $1.15^{\mathrm{c}} \pm 0.01$ \\
\hline
\end{tabular}

Values show means of triplicate analysis \pm standard deviation. Figures with different superscripts down the column, are significantly different $(p<0.05)$.

The alkaloid content of the plant species ranged from $0.23^{\mathrm{a}} \pm$ 0.01 in Citrus sinensis to $1.31^{\mathrm{d}} \pm 0.03$ in Vernonia amygdalina the flavonoid content of the plant species ranged from $0.33^{\mathrm{a}} \pm 0.01$ in Citrus sinensis to $0.71^{\mathrm{d}} \pm 0.02$ in Vernonia amygdalina. Saponin content of plant species varied from $0.19^{\mathrm{a}} \pm 0.01$ in Citrus paradisi to $1.15^{\mathrm{c}} \pm 0.01$ in Vernonia amygdalina. Tannin content of plant leaf extracts ranged from $0.15^{\mathrm{a}} \pm 0.01$ to $0.43^{\mathrm{c}} \pm 0.01$ in Vernonia amygdalina. HCN $(\mathrm{mg} / \mathrm{kg})$ content of the plant leaf extracts varied from $3.77^{\mathrm{a}} \pm 0.09$ in Vernonia amygdalina to $11.25^{\mathrm{d}} \pm 0.25$ in Carica papa$y a$. Phytate content of the plants ranged from $0.27^{\mathrm{a}} \pm 0.01$ in Vernonia amygdalina to $0.45^{\mathrm{a}} \pm 0.01$ in Citrus sinensis. While the phenol content of the leaf extracts of the plant ranged from $0.52^{\mathrm{a}} \pm 0.04$ in Citrus paradisi to $1.15^{\mathrm{c}} \pm 0.01$ in Vernonia amygdalina. Apart from HCN $\left(3.77^{\mathrm{a}} \pm 0.09\right)$ and phytate $\left(0.27^{\mathrm{a}} \pm 0.01\right)$, all the phytochemicals contents were highest in Vernonia amygdalina. All the phytochemicals were also high in Carica papaya.

Table 3: Antimicrobial Activity of Aqueous and Ethanolic Extracts of leaves of Citris paradisi, Citrus sinensis Carica papaya and Vernonia amygdalina.

\begin{tabular}{|c|c|c|c|c|}
\hline Sample & Salmonella pullorum & Klebsiella pneumonia & Enterobacter aerogenes & Proteus vulgaris \\
\hline \multicolumn{5}{|c|}{ Carica papaya } \\
\hline $\mathrm{H}_{2} \mathrm{O}$ & $11.33^{c} \pm 0.58$ & $12.67^{\complement} \pm 0.58$ & $9.67^{\mathrm{b}} \pm 1.16$ & $12.33^{\mathrm{b}} \pm 1.16$ \\
\hline Ethanol & $14.67^{\mathrm{e}} \pm 1.16$ & $18.67^{\mathrm{d}} \pm 1.16$ & $13.33^{\mathrm{d}} \pm 0.58$ & $14.67^{c} \pm 1.53$ \\
\hline \multicolumn{5}{|c|}{ Citrus paradisi } \\
\hline $\mathrm{H}_{2} \mathrm{O}$ & $7.33^{\mathrm{b}} \pm 0.58$ & $6.33^{a} \pm 0.58$ & $6.33^{a} \pm 0.58$ & $8.33^{a} \pm 0.58$ \\
\hline Ethanol & $11.67^{\complement} \pm 1.16$ & $10.67^{\mathrm{b}} \pm 0.58$ & $10.33^{\mathrm{b}} \pm 0.58$ & $13.33^{\mathrm{bc}} \pm 0.58$ \\
\hline \multicolumn{5}{|c|}{ Citrus sinensis } \\
\hline $\mathrm{H}_{2} \mathrm{O}$ & $0.00^{\mathrm{a}} \pm 0.00$ & $10.67^{\mathrm{b}} \pm 0.58$ & $10.33^{\mathrm{b}} \pm 0.58$ & $13.33^{\mathrm{bc}} \pm 0.58$ \\
\hline Ethanol & $10.33^{c} \pm 1.16$ & $12.00^{c} \pm 1.00$ & $11.33^{c} \pm 1.16$ & $14.33^{c} \pm 0.58$ \\
\hline \multicolumn{5}{|c|}{ Vernonia amygdalina } \\
\hline $\mathrm{H}_{2} \mathrm{O}$ & $15.67^{f} \pm 1.16$ & $15.33^{\mathrm{d}} \pm 0.58$ & $14.67^{\mathrm{d}} \pm 0.58$ & $17.67^{\mathrm{d}} \pm 1.53$ \\
\hline
\end{tabular}




\section{Journal of Dairy \& Veterinary Sciences}

\begin{tabular}{|c|c|c|c|c|c|}
\hline Ethano & \multicolumn{4}{|c|}{$13.33^{\mathrm{d}} \pm 0.58$} & $14.67^{\mathrm{d}} \pm 0$ \\
\hline \multicolumn{6}{|c|}{$\begin{array}{l}\text { Values show means of triplicate analysis } \pm \text { standard deviation. Figure } \\
(p<0.05) \text {. }\end{array}$} \\
\hline \multicolumn{6}{|c|}{$\begin{array}{l}\text { Table 4: MIC of extracts of leaves of Carica papaya, Citrus paradisi, } \\
\text { Citrus sinensis and Vernonia amygdalina concentrations }(\mathrm{mg} / \mathrm{ml}) \text { on } \\
\text { Salmonella pullorum. }\end{array}$} \\
\hline Sample & 200 & 150 & 100 & 50 & $\mathrm{MIC} \mathrm{mg} / \mathrm{ml}$ \\
\hline \multicolumn{6}{|c|}{ Carica papaya } \\
\hline $\mathrm{H}_{2} \mathrm{O}$ & 10.67 & 0.0 & 0.0 & 0.0 & $200 \mathrm{mg} / \mathrm{ml}$ \\
\hline Ethanol & 14.33 & 9.33 & 0.0 & 0.0 & $150 \mathrm{mg} / \mathrm{ml}$ \\
\hline \multicolumn{6}{|c|}{ Citrus paradisi } \\
\hline $\mathrm{H}_{2} \mathrm{O}$ & 6.67 & 0.0 & 0.0 & 0.0 & $200 \mathrm{mg} / \mathrm{ml}$ \\
\hline Ethanol & 10.33 & 0.0 & 0.0 & 0.0 & $200 \mathrm{mg}$ \\
\hline \multicolumn{6}{|c|}{ Citrus sinensis } \\
\hline $\mathrm{H}_{2} \mathrm{O}$ & 0.0 & 0.0 & 0.0 & 0.0 & Nil \\
\hline Ethanol & 9.67 & 0.0 & 0.0 & 0.0 & $200 \mathrm{mg} / \mathrm{ml}$ \\
\hline \multicolumn{6}{|c|}{ Vernonia amygdalina } \\
\hline $\mathrm{H}_{2} \mathrm{O}$ & 15.67 & 12.33 & 9.3 & 0.0 & $100 \mathrm{mg} / \mathrm{ml}$ \\
\hline Ethanol & 14.0 & 10.33 & 0.0 & 0.0 & $150 \mathrm{mg} / \mathrm{ml}$ \\
\hline
\end{tabular}

Table 5: MIC of extracts of leaves of Carica papaya, Citrus paradisi, Citrus sinensis and Vernonia amygdalina concentrations $(\mathrm{mg} / \mathrm{ml})$ on Klebsiella pneumonia.

\begin{tabular}{|c|c|c|c|c|c|}
\hline Sample & $\mathbf{2 0 0}$ & $\mathbf{1 5 0}$ & $\mathbf{1 0 0}$ & $\mathbf{5 0}$ & MIC mg/ml \\
\hline \multicolumn{6}{|c|}{ Carica papaya } \\
\hline $\mathrm{H}_{2} \mathrm{O}$ & 12.33 & 8.33 & 0.0 & 0.0 & $150 \mathrm{mg} / \mathrm{ml}$ \\
\hline Ethanol & 15.33 & 11.67 & 7.67 & 0.0 & $100 \mathrm{mg} / \mathrm{ml}$ \\
\hline \multicolumn{7}{|c|}{ Citrus paradisi } \\
\hline $\mathrm{H}_{2} \mathrm{O}$ & 6.33 & 0.0 & 0.0 & 0.0 & $200 \mathrm{mg} / \mathrm{ml}$ \\
\hline Ethanol & 10.33 & 0.0 & 0.0 & 0.0 & $200 \mathrm{mg} / \mathrm{ml}$ \\
\hline \multicolumn{7}{|c|}{ Citrus sinensis } \\
\hline $\mathrm{H}_{2} \mathrm{O}$ & 6.67 & 0.0 & 0.0 & 0.0 & $200 \mathrm{mg} / \mathrm{ml}$ \\
\hline Ethanol & 10.67 & 0.0 & 0.0 & 0.0 & $200 \mathrm{mg} / \mathrm{ml}$ \\
\hline \multicolumn{7}{|c|}{ Vernonia amygdalina } \\
\hline $\mathrm{H}_{2} \mathrm{O}$ & 15.33 & 11.67 & 8.33 & 0.0 & $100 \mathrm{mg} / \mathrm{ml}$ \\
\hline Ethanol & 14.00 & 11.67 & 0.00 & 0.0 & $150 \mathrm{mg} / \mathrm{ml}$ \\
\hline
\end{tabular}

Table 3 show the antimicrobial activity of the plants. From the result, they were valid in the level of activity of the different plant extracts against the different organisms. In general, the extracts were more patent than the water extracts. Ethanol extract of Carica papaya showed the highest zone of inhibition $\left(18.67^{\mathrm{d}} \pm\right.$ 1.16) against Klebsiella pneumonia while aqueous extract of Citrus sinensis showed no inhibition against Salmonella pullorum $\left(0.00^{a} \pm 0.00\right)$. Bitter leaf extracts exhibited high levels of activity against the test organisms relative to the citrus plants (grape and orange leaves). The plants were adjudged to possess potential for pharmaceutical applications. Results of minimum inhibition concentration (MIC) as shown in Tables 4-7, apart from the aqueous extract of Citrus sinensis that showed inhibition at $150 \mathrm{mg} / \mathrm{ml}$ for Proteus vulgaris the MIC for Citrus paradise and Citrus sinensis had

a minimum inhibition concentration of $200 \mathrm{mg} / \mathrm{ml}$ for all the clinical isolates. Carica papaya and Vernonia amygdalina had and MIC between $100 \mathrm{mg} / \mathrm{ml}$ and $200 \mathrm{mg} / \mathrm{ml}$ for the test organisms studied.

Table 6: MIC of extracts of leaves of Carica papaya, Citrus paradisi, Citrus sinensis and Vernonia amygdalina concentrations $(\mathrm{mg} / \mathrm{ml})$ on Enterobacter aerogenes.

\begin{tabular}{|c|c|c|c|c|c|}
\hline Sample & $\mathbf{2 0 0}$ & $\mathbf{1 5 0}$ & $\mathbf{1 0 0}$ & $\mathbf{5 0}$ & MIC mg/ml \\
\hline \multicolumn{7}{|c|}{ Carica papaya } \\
\hline $\mathrm{H}_{2} \mathrm{O}$ & 9.0 & 0.0 & 0.0 & 0.0 & $200 \mathrm{mg} / \mathrm{ml}$ \\
\hline Ethanol & 11.67 & 0.0 & 0.0 & 0.0 & $200 \mathrm{mg} / \mathrm{ml}$ \\
\hline \multicolumn{7}{|c|}{ Citrus paradisi } \\
\hline $\mathrm{H}_{2} \mathrm{O}$ & 6.67 & 0.0 & 0.0 & 0.0 & $200 \mathrm{mg} / \mathrm{ml}$ \\
\hline Ethanol & 9.67 & 0.0 & 0.0 & 0.0 & $200 \mathrm{mg} / \mathrm{ml}$ \\
\hline \multicolumn{7}{|c|}{ Citrus sinensis } \\
\hline $\mathrm{H}_{2} \mathrm{O}$ & 6.33 & 0.0 & 0.0 & 0.0 & $200 \mathrm{mg} / \mathrm{ml}$ \\
\hline Ethanol & 11.33 & 0.0 & 0.0 & 0.0 & $200 \mathrm{mg} / \mathrm{ml}$ \\
\hline \multicolumn{7}{|c|}{ Vernonia amygdalina } \\
\hline $\mathrm{H}_{2} \mathrm{O}$ & 15.00 & 11.33 & 0.0 & 0.0 & $150 \mathrm{mg} / \mathrm{ml}$ \\
\hline Ethanol & 12.33 & 8.33 & 0.00 & 0.0 & $150 \mathrm{mg} / \mathrm{ml}$ \\
\hline
\end{tabular}

Table 7: MIC of extracts of leaves of Carica papaya, Citrus paradisi, Citrus sinensis and Vernonia amygdalina concentrations $(\mathrm{mg} / \mathrm{ml})$ on Proteus vulgaris.

\begin{tabular}{|c|c|c|c|c|c|}
\hline Sample & $\mathbf{2 0 0}$ & $\mathbf{1 5 0}$ & $\mathbf{1 0 0}$ & $\mathbf{5 0}$ & MIC $\mathbf{~ m g} / \mathrm{ml}$ \\
\hline \multicolumn{7}{|c|}{ Carica papaya } \\
\hline $\mathrm{H}_{2} \mathrm{O}$ & 12 & 0.0 & 0.0 & 0.0 & $200 \mathrm{mg} / \mathrm{ml}$ \\
\hline Ethanol & 14 & 9 & 0.0 & 0.0 & $150 \mathrm{mg} / \mathrm{ml}$ \\
\hline \multicolumn{7}{|c|}{ Citrus paradisi } \\
\hline $\mathrm{H}_{2} \mathrm{O}$ & 8 & - & - & - & $200 \mathrm{mg} / \mathrm{ml}$ \\
\hline Ethanol & 10 & - & - & - & $200 \mathrm{mg} / \mathrm{ml}$ \\
\hline \multicolumn{7}{|c|}{ Citrus sinensis } \\
\hline $\mathrm{H}_{2} \mathrm{O}$ & 8 & - & - & - & $200 \mathrm{mg} / \mathrm{ml}$ \\
\hline Ethanol & 12 & 9 & - & - & $150 \mathrm{mg} / \mathrm{ml}$ \\
\hline \multicolumn{7}{|c|}{ Vernonia amygdalina } \\
\hline $\mathrm{H}_{2} \mathrm{O}$ & 16 & 13 & 11 & - & $100 \mathrm{mg} / \mathrm{ml}$ \\
\hline Ethanol & 14 & 10 & - & - & $150 \mathrm{mg} / \mathrm{ml}$ \\
\hline
\end{tabular}

\section{Discussion}

The phytochemical and antimicrobial properties of Carica papaya, Citris paradisi, Citrus sinensis and Vernonia amygdalina, from aqueous and ethanolic extracts revealed the presence of chemical constituents which have been shown to possess some pharmacological activities. The presence of these phytochemicals in the plants indicate that the plant possesses potentials to be useful in ethnomedicine. Sofowora [19] observed that the efficacy of plants in traditional medicine was due to their phytochemical contents. The result in Table 2 show that the concentration of the different 
phytochemicals varied significantly between the test plants. The high alkaloid content means that the leaves can be useful medicinally. Alkaloid are required presently due to their high pharmacological activity rather than their toxicity. Flavonoids was moderate in the plants, while phenols were high. Flavonoid and phenols are antioxidant components which can protect the body against oxidative cell destruction [13].

The level of HCN in the leaves is low even though the component is known to be toxic [23]. However, the toxicity is significant at $50 \mathrm{mg} / \mathrm{ml}$. Phytate is an antinutrient that chelates dietary minerals thereby interfering with digestion. The level is moderate in the leaves. But reports show that normal heat processing of vegetables and leaves, reduces it and sometimes eliminate it completely. Generally, the quantity of these chemicals in the plant imply that they will be good sources of these components for possible drug production. The relativity high concentrations required to initiate antimicrobial activity was altered since the extracts were in crude form and may improve if purified. According to the antibacterial assay done for screening purpose, all extracts in general are more effective on Gram-positive bacteria than on Gram-negative bacteria. The results are in line with observations of previous researchers and could be explained by the different cell wall structures of these bacteria. Gram-negative outer membrane comprising of phospholipids and lipopolysaccharides act as a barrier to the penetration and reaction of most antibiotics and / or antimicrobial agents through cell envelope [26]. The variations in the sensitivity of the microbial isolates tested on the extracts might be due to differences in the strains used for the study and perhaps local environmental factors that affect the potency of medicinal plants, such as temperature, rainfall, and soil properties may have differed between the plant's samples used for the research [27].

\section{Conclusion}

In this project work, it can be concluded that the leaves of Carica papaya, Citris paradisi, Citrus sinensis and Vernonia amygdalina, have antimicrobial activity and phytochemical constituents such as flavonoid, tannin, saponin and phenols which shows that they have medicinal value which can be used to treat different ailments. It was also observed that ethanol extract exhibited high activity on the test organisms. This can be deduced to the ability of ethanol to extract more of secondary plant metabolites which are believed to exert antimicrobial activity on the test organism. Also, further studies should be carried out to identify other useful benefits of the plant and how it can be employed in the pharmaceutical industries in producing drugs. It is therefore recommended that leaves of Carica papaya, Citris paradisi, Citrus sinensis and Vernonia amygdalina, should be used in treatment of various ailments and diseases due to their phytochemical constituents and their antimicrobial activities.

\section{References}

1. Almonam, Abu-Basha, WE, Janakart S, Nicholas RN, Ailing RD (2007) In-Vitro Antiplasmal Activity of Six Jordan Medicinal Plants against Three Mycoplasma Species. Trop. Animal Health Production 39: 515-
519.

2. Kapoor LD (2001) Handbook of Ayuruedic Medicinal Plants. CRC Press Florida, USA, pp. 416.

3. Prusti A, Mishra SR, Sahov S, Mishra SK (2008) Antimicrobial Activity of Some Indian Medicinal Plants. A. Ethionotanical Leaflets. 12: 227230.

4. Hemaiswarya S, Kruthiventi AK, Doble M (2008) Synergism between natural products and antibiotics against infectious diseases. Phytomedicine 15: 639-652.

5. Muhammed HS, Muhammed S (2005) The Use of Lawsonia Inersmis Linn. In the Management of Burn Wounds Infections. Afri J Bitechnol, 4(9): 934-937.

6. Harbone B (1999) Phytochemical Methods: Chapman A Guide to Modern Techniques of Plant Analysis. Chapman and Hall Co. New York, USA.

7. Zhang H, Ma ZF (2018) Phytochemical and Pharmacological Properties of Capparis spinosa as a Medicinal Plant. Nutrient, 10(2): 116.

8. Elansary HO, Szopa A, Kubica P, Ekiert H, Ali HM, et al. (2018) Bioactivities of Traditional Medicinal Plants in Alexandria. Evidence - Based Complementary and Alternative Medicine 32(1): 1-13.

9. Okwu DE (2001) Evaluation of the Chemical Composition of Indigenous Species and Flavoring Agents. Global J Pure Appl Sci 7(3): 445459.

10. Bratner A, Grein E (1994) Antibacterial Activity of Plant Leaf Extract Used Externally in Traditional Medicine. J Ethnophamacol 44: 35-40.

11. Ali SS, Kasoju N, Hithra A, Singh A, Sharanabasava H, et al. (2008) Indian Medicinal Herbs as Source of Antioxidants. Food Res Int 41: 1-15.

12. Morton JF (1987) Papaya A New Crop, The New Crop Resource Online Program, Center for New Crops and Plant Products, pp. 336-346.

13. Kim SY, Kim JH, Kim SK, Ohandy J (1994) Antioxidants Activities of Selected Oriental Herbs Extracts. Journal America Oil Chemical Social 71: 633-640.

14. Hemood VH, Brummih RK, Cullarm A, Sebe O (2007) Flowering Plant Families of the World.

15. Duarte A, Caixenho D, Miguel G, Nune SC, Mendes M, et al. (2010) Vitamin C Content of Citrus from Conventional Versus Organic Farming System. Alta Horticulture 868: 389-394.

16. Julius O, Ebangha E, Shill K, Walter C, Robert G, et al. (2009) Phellodendwn and Citrus Extracts Benefit in Health in Ostheo Arthritis Patients: A Pilot, Double-Blind, Placebo-Controlled Study. Biomed Central 1: 8-38.

17. Song YJ, Lee DY, Kim SN, Lee KR, Lee HW (2005) Apoptotic Potential of Seequiterpere Lactoneergolide through the Inhibition of NF. I. B. Signaling pathway. J Pharmacol 4 (8): 46-52.

18. Sweeny C, Mehrota S, Sadaria MR, Kumar S, Shortle NH, et al. (2005) The Sesgultaperu Lactoru Partjenoli De in Combination with Docetarel Reduces Metastatisis With and Improve Survival In. Xenogratt Model of Breast Cancer Mole Cancer Ther 4(6): 1004.

19. Sofawara A (1993) Medicinal Plants and Traditional Medicine in Africa. Spectrum Books Ltd, Ibadan Nigeria, pp. 191-289.

20. Yadav RN, Agarwala M (2011) Phytochemical analysis of some medicinal plants. J Phytology 3: 12.

21. Tyler V (1994) Phytomedicines in Western Europe: their potential impact on herbal medicine in the United States Herbalgram. 30: 24-30.

22. Obadoni BO, Ochuku PO (2001) Phytochemical Studies and Comparative Efficacy of the Crude Extracts of Some Homeostatic Plants in Edo and Delta states in Nigeria. Global Journal of Pure Applied Science 7(3): 455-459. 
23. Onwuka GI (2005) Food Analysis and instrumentation. Theory and practice. Napthali prints, Nigeria, pp. $14-146$.

24. Cheesebrough M, Ijli K, Shinbowa Y (2000) District laboratory practice in tropical countries part 2. Cambridge University press, UK, Journal of Laboratory Science, 11: 0204-0207.

25. Perez C, Paul M, Bazerque P (1990) Antibiotic Assay by Agar Well diffusion Method. Acta Bio Med Exp 15: 113-115.
26. Baron EJ, Peterson LR, Finegold SM (1994) Baily and Scott's Diagnostic Microbiology. ( $9^{\text {th }}$ edn), St. Louis: Mosby-Year Book Inc, USA.

27. Mehrotra S, Srivastava AK, Nandi SP (2010) Comparative antimicrobial activities of neem, amla, aloe, Assam tea and clove extracts against Vibrio cholerae, Staphylococcus aureus and Pseudomonas aeruginosa. J Med Plants Res 4: 2393-2398.
This work is licensed under Creative Commons Attribution 4.0 License

DOI: 10.19080/JDVS.2019.09.555768 